\title{
Gumprecht shadows: when to use this terminology?
}

\section{Sombras de Gumprecht: quando usar essa terminologia?}

Luci Maria Sant’Ana Dusse ${ }^{1}$; Tamiris Paula Silva²; Letícia Gonçalves Freitas³;

Lauro Mello Vieira'; Adriano de Paula Sabino5; Maria das Graças Carvalho ${ }^{6}$

\begin{abstract}
The expression Gumprecht shadows historically refers to lymphocyte lysates commonly observed in patients with chronic lymphocytic leukemia (CLL). A literature review revealed that this term is restricted to CLL cases, and should not be applied to lymphocytosis-related conditions. Inappropriate use of this term can cause great anxiety in individuals receiving their blood count results, as well as in their families. In a web search engine commonly used to clear doubts on medical terms, there are countless pages where Gumprecht shadows are associated with CLL.
\end{abstract}

Key words: Gumprecht; chronic lymphocytic leukemia; viruses.

\section{INTRODUCTION}

The expression Gumprecht shadows derived from the German researcher Ferdinand Adolph Gumprecht ${ }^{(42)}$, as he observed the blood films of patients with chronic lymphocytic leukemia (CLL) (Figure).

CLL is a relatively rare lymphoproliferative disorder. It is benign in comparison to other leukemias, shows slow evolution and marked leukocytosis in the blood ${ }^{(25)}$. Most of the times, CLL is unexpectedly diagnosed by a routine blood test. However, only the morphological aspects of lymphocytes do not allow differentiation between B- and T-CLL type. More sophisticated techniques are required for the proper classification ${ }^{(25)}$.

CLL is suspected when the blood film reveals an expressive increase in uniform-appearing lymphocytes and the presence of destroyed lymphocytes. The ruptured lymphocytes, stained in pink, show themselves irregular and constitute the Gumprecht shadows $^{(14)}$.

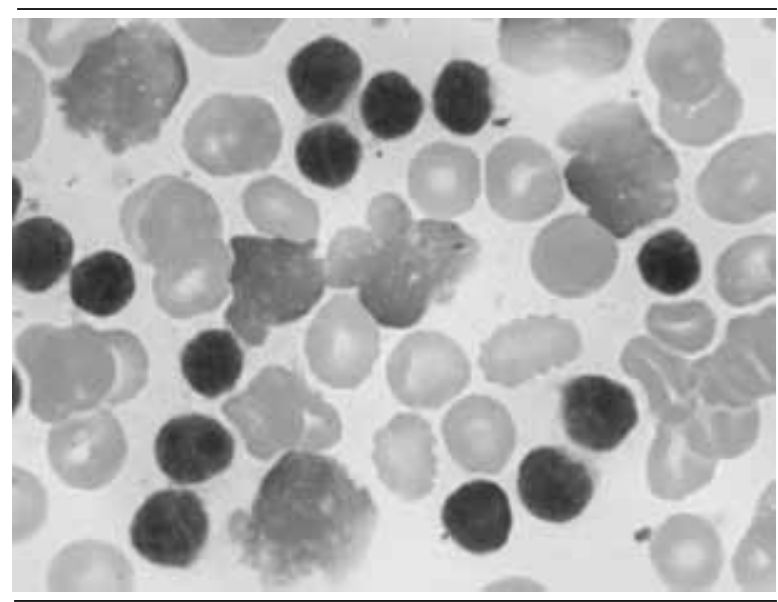

FIGURE - Lymphocytes and Gumprecht shadows

The microscopic examination of blood cells is surely an essential step for the diagnosis of CLL: the hematological picture, with the presence of relative and absolute lymphocytosis, will require investigation of the suspicion initially raised by the blood count. Although more sophisticated methods, such as flow cytometry and cytogenetics, are currently used to refine this

First submission on 18/03/13; last submission on 18/03/13; accepted for publication on 18/06/13; published on 20/10/13

1. Doctorate in Clinical Laboratory Science from Universidade de São Paulo (USP); associate professor at Faculdade de Farmácia da Universidade Federal de Minas Gerais (UFMG).

2. Graduating student of Biomedicine at UFMG

3. Doctoral student of the postgraduate Program of Pharmacy at Faculdade de Farmácia of UFMG.

4. Doctorate in Pharmacy from UFMG; associate professor at Faculdade de Farmácia of UFMG.

5. Doctorate in Pharmacy from UFMG; assistant professor at Faculdade de Farmácia of UFMG.

6. Doctorate in Hematology from the University of Southampton/United Kingdom; full professor at Faculdade de Farmácia of UFMG. 
diagnosis ${ }^{(29)}$, the initial suspicion comes from cell morphology observed in the blood film.

Flow cytometry allows identification of cluster differentiation (CD) specific to B lymphocytes (CD14, CD20, and CD23) and, as a result, characterizes the clonal origin of these lymphocytes ${ }^{(38)}$. Cytogenetics helps to detect abnormalities, especially in chromosomes 11 and 17. Besides, serum determination of lactate dehydrogenase $(\mathrm{LDH})$, bilirubin, immunoglobulins, and antiglobulins composes the test panel currently used to diagnose $\mathrm{CLL}^{(6)}$.

An extensive literature review demonstrated that the expression Gumprecht shadows gradually lost importance in the CLL diagnosis, as more precise methods were established for that purpose. Thus, the most frequently used textbooks in English ${ }^{(4-10)}$ or Portuguese ${ }^{(1-3,5,7-11,15,16-28,30-35,39-41,43-45)}$ in our setting do not refer to this term, although older literature values Gumprecht shadows for the diagnosis of CLL.

It is known that viral conditions present with a high number of circulating lymphocytes, which are also susceptible to lysis. In the blood film, lymphocyte lysates, resulting from viral infection, present similar aspects to those described by Gumprecht to refer to lymphocyte lysates at $\mathrm{CLL}^{(42)}$.

A search in the PubMed database using terms Gumprecht chronic lymphocytic leukemia revealed just five reports ${ }^{(4,12,13,36,37)}$, what confirms that the term has fallen into disuse.

The World Health Organization (WHO) describes CLL as a neoplasm of small B lymphocytes, with slightly irregular membrane present in peripheral blood, bone marrow, spleen and lymph nodes, along with prolymphocytes and paraimmunoblasts that proliferate in the infiltrated tissues ${ }^{(38)}$.

Nowadays, the diagnosis of CLL is based on criteria revised at the International Workshop on CLL (IWCLL), held in $2008^{(6,14)}$ that include: a) presence of at least $5,000 \mathrm{~B}$ lymphocytes/ $\mu \mathrm{l}$ in peripheral blood in the last three months, with their clonality being confirmed by flow cytometry; b) presence of small typical mature lymphocytes, with scant cytoplasm and nucleus with intensely stained chromatin. Atypical cells (prolymphocytes) correspond to less than $5 \%$.

Leukemic lymphocytes co-express the $\mathrm{CD} 5$ marker and the B lymphocyte-specific surface antigen (CD19, CD20, and CD23). The serum levels of immunoglobulins $\mathrm{CD} 20$ and $\mathrm{CD} 79 \mathrm{~b}$ are significantly reduced in comparison to normal B-lineage cells. Each leukemic clone expresses $\kappa$ or $\lambda$ light chain immunoglobulin. On the other hand, in lymphomas, although cells express B-lymphocyte and CD5 surface antigens, they normally do not express CD23.

Before begining immunosuppressive therapy, the following is recommended: 1) detailed anamnesis and physical examination, including careful palpation of all lymph node areas, spleen and liver; 2) conduction of a complete blood count; 3 ) determination of LDH activity, serum levels of bilirubin and immunoglobulins, and direct antiglobulin test; 4) investigation of the presence of infections, such as hepatitis types B and C, cytomegalovirus, and the human immunodeficiency virus (HIV) ${ }^{(14)}$.

Additional tests may be ordered, such as bone marrow biopsy for exclusion of idiopathic cytopenias; detection of genetic abnormalities, principally of a deletion of chromosomes 17 [del(17p)] and 11 [del(11q)]; flow cytometry to evaluate ZAP-70 and CD38 expression, whose presence indicates poor prognosis; and computed tomography (CT) for the staging of the disease ${ }^{(14)}$.

Since the presence of viroses may cause the appearance of images similar to those observed in CLL because of lymphocyte lysis, a literature review was undertaken by searching the word Gumprecht referring to images of lymphocyte lysates that occur in viral diseases. After a thorough and careful search, only a doctoral dissertation was found, in the area of Veterinary Medicine, where this term was used ${ }^{(37)}$. However, a search in a web search engine using the term Gumprecht and lymphocytes revealed innumerable pages where it is associated with CLL.

In face of the ambiguous use of the term Gumprecht shadows in clinical situations of distinct prognosis and evolution, it would be quite pertinent to keep using it in cases of CLL, principally knowing that absolute lymphocytosis in peripheral blood is not always a sign of malignancy. Since hyperplasia of lymphoid tissues and lymphocytosis may occur in other infectious processes, especially viral diseases, and in chronic inflammatory processes, such as arthritis, lupus erythematosus, vasculitis, sarcoidosis, etc. ${ }^{(1)}$, a blood test presenting Gumprecht shadows in cases of marked lymphocytosis could reinforce the suspicion of CLL.

It should be noted that the mechanisms of lymphocyte destruction in CLL and in viral diseases are distinct. In viral diseases, the ruptured lymphocytes are younger normal-appearing cells that go through lysis as a consequence of viral infection. In CLL, this process is due to cell aging. In this case, lymphocytosis occurs when old cells accumulate, because the apoptosis mechanism is impaired ${ }^{(25)}$.

\section{CONCLUSION}

The expression Gumprecht shadows must be used only for cases of CLL, not to describe ruptured lymphocytes present in other situations with lymphocytosis, associated with either viral diseases 
or other causes. The inappropriate use of this term may cause great anxiety in individuals who receive this observation in their blood count, as well as to their families, since information on the internet is available to any person and is frequently used to clear doubts on medical terms.

\section{ACKNOWLEDGEMENTS}

Fundação de Amparo à Pesquisa do Estado de Minas Gerais (FAPEMIG) and Conselho Nacional de Desenvolvimento Científico e Tecnológico (CNPq).

\section{RESUMO}

A locução sombras de Gumprecht refere-se, historicamente, aos linfócitos lisados comumente observados em portadores de leucemia linfocítica crônica (LLC). Uma revisão da literatura revelou que esse termo restringe-se aos casos de LLC e não deve ser utilizado em outras situações que cursam com linfocitose. A utilização inapropriada dessa terminologia pode gerar ansiedade no indivíduo que recebe tal observação no hemograma, bem como em seus familiares. Em um site de busca da internet muito utilizado para sanar dúvidas relativas a termos clínicos, há inúmeras páginas com relatos nos quais essa expressão associa-se à LLC.

Unitermos: Gumprecht; leucemia linfocítica crônica; viroses.

\section{REFERENCES}

1. BAIN, B. J. Diagnóstico em leucemias. 2. ed. Rio de Janeiro: Revinter, 2003.

2. BAIN, B. J. Células sanguíneas: um guia prático. 3. ed. Porto Alegre: Artmed, 2004.

3. BAIN, B. J. Células sanguíneas: um guia prático. 4. ed. Porto Alegre: Artmed, 2007.

4. BINET, J. L. et al. Basket cells or shadow cells of Gumprecht: a scanning electron microscope study, and the correlation between percentages of basket cells, and cells with altered chromatin structure (dense cells), in chronic lymphocytic leukemia. Blood Cells, v. 19, n. 3, p. 573-81, 1993.

5. CISCAR, R. F.; FARRERAS, P. V. Diagnóstico hematológico: laboratorio y clínica. 3. ed. Barcelona: Jims, 1972. 2v.

6. EICHHORST, B. et al. On behalf of the ESMO Guidelines Working Group. Chronic lymphocytic leukemia: ESMO clinical practice guidelines for diagnosis, treatment and follow-up. Clinical practice guidelines. Annals of Oncology, v. 22, Suppl., p. vi50-4, 2011.

7. FAILACE, R. R. Hemograma: manual de interpretação. 3. ed. Porto Alegre: Artmed, 1995.

8. FAILACE, R. R. Hemograma: manual de interpretação. 4. ed. Porto Alegre: Artmed, 2003.

9. FAILACE, R. R. Hemograma: manual de interpretação. 5. ed. Porto Alegre: Artmed, 2009.

10. FAMADAS, L. C. Hemopatias malignas: classificação clínica, citológica e histopatológica - estadiamentos. Rio de Janeiro: Revinter, 1996.

11. FIGUEIRED0, M. S. et al. Escola paulista de medicina. Guia de hematologia. São Paulo: Manole, 2010.

12. Guillaume, N. et al. Pertinence des analyses cytologiques et immunophénotypiques dans le diagnostic de la leucémie lymphoïde chronique B.Annales de Biologie Clinique, v. 60, n. 6, p. 673-8, 2002.
13. GUILLAUME, N. et al. Relevance of cytological and immunophenotypical analysis for the diagnosis of B-cell chronic lymphocytic leukaemia.Ann Biol Clin, v. 60, n. 6, p. 673-81, 2002.

14. HALLEK, M. et al. Guidelines for the diagnosis and treatment of chronic lymphocytic leukemia: a report from the International Workshop on Chronic Lymphocytic Leukemia updating the National Cancer Institute Working Group 1996 guidelines. Blood, v. 111, n. 12, p. 5446-56, 2008.

15. HAMERSCHLAK, N. Manual de hematologia. 1. ed. São Paulo: Manole, 2010.

16. HAYHOE, F. G. J.; FLEMANS, R. J. Um atlas colorido de citologia hematológica. 3. ed. Porto Alegre: Artmed, 1997.

17. JAMRA, M.; LORENZI, T. F. Leucócitos, leucemias, linfomas. Rio de Janeiro: Guanabara Koogan, 1983.

18. JANNINI, P.Interpretação clínica do hemograma. [S.1.]: [s.n.], 1949. 19. JANNINI, P. Interpretação clínica do hemograma. 2. ed. [S.I.]: [s.n.], 1955.

20.JANNINI, P.; JANNINI,P.F.Compêndio de fisiopatologia hematológica. São Paulo: [s.n.], 1972.

21.JANNINI, P.;JANNINI, P.F.Compêndio de fisiopatologia hematológica. 2. ed. São Paulo: Rev. e Ampl., 1975.

22. LICHTMAN, M. A. et al. Manual de hematologia de Williams. 6. ed. Porto Alegre: Artmed, 2005.

23. LORENZI, T. F. et al.Manual de hematologia, propedêutica e clínica. 2. ed. Rio de Janeiro: Medsi Editora Médica e Científica Ltda., 1999.

24. LORENZI, T. F. et al.Manual de hematologia, propedêutica e clínica. 3. ed. Rio de Janeiro: Medsi Editora Médica e Científica Ltda., 2003.

25. LORENZI, T. F. et al.Manual de hematologia, propedêutica e clínica. 4. ed. Rio de Janeiro: Medsi Editora Médica e Científica Ltda., 2006.

26. MARINHO, H. M. Hematologia. São Paulo: Sarvier, 1984.

27. MAZZA, J. J. Manual of clinical hematology. 2. ed. Boston: Little Brown, 1994. 
28. MCDONALD, G. A.; PAUL, J.; CRUICKSHANK, B. Atlas de hematologia. 5. ed. São Paulo: Panamericana, 1989.

29. NIERO-MELO, L. et al. Diretrizes para diagnóstico morfológico em síndromes mielodisplásicas [Guidelines for morphological diagnosis of myelodysplastic syndromes]. Rev Bras Hematol Hemot, v. 28, n. 3 , p. 167-74, 2006

30. OLIVEIRA, H. P. Hematologia clínica. 2. ed. São Paulo: Atheneu, 1983.

31. PILLOT, G. et al. Hematologia e oncologia. 1. ed. Rio de Janeiro: Guanabara Koogan, 2005. (The Washington Manual Série Consultas).

32. RAPAPORT, S. I. Hematologia: uma introdução. 2. ed. São Paulo: Roca, 1990.

33. ROSENFELD, R. Fundamentos do bemograma: do laboratório à clínica. Rio de Janeiro: Guanabara Koogan, 2007.

34. SACHER, R. A.; MCPHERSON, R. A. Widmann: interpretação clínica dos exames laboratoriais. 11. ed. São Paulo: Manole, 2002

35. SILVA, P. H.; HASHIMOTO, Y. Interpretação laboratorial do eritrograma: texto \& atlas. São Paulo: Lovise, 1999.

36. SMETANA, K.; KARBAN, J.; TRNENY, M. To the nucleolar bodies (nucleoli) in cells of the lymphocytic lineage in patients suffering from B-chronic lymphocytic leukemia.Neoplasma, v. 57, n. 6, p. 495-500, 2010. 37. SPINOLA, T. R. Correlação entre a atipia linfocitária e o perfil imunológico de animais infectados pelo vírus da leucose enzoótica bovina. 2010. Dissertação (mestrado) - Faculdade de Medicina Veterinária e Zootecnia, Universidade de São Paulo, 2010.

38. SWERDLOW, S. H. et al. (Eds.). World Health Organization classification of tumours of haematopoietic and lymphoid tissues. 4. ed. Lyon: International Agency for Research on Cancer, 2008.

39. VARELA, M. E. Hematologia clínica. 4. ed. Buenos Aires: El Ateneo, 1958.

40. VERRASTRO, T. F.; LORENZI, T.; NETO, S. W. Hematologia e bemoterapia: fundamentos de morfologia, fisiologia, patologia e clínica. Rio de Janeiro: Atheneu, 2002.

41. WALLACH, J. B. Interpretação de exames laboratoriais. 8. ed. Rio de Janeiro: Guanabara Koogan, 2009.

42. WHONAMEDIT? A dictionary of medical eponyms. Available at: $<$ http://www.whonamedit.com/doctor.cfm/2828.html>. Accessed on: 15 mar. 2013 .

43. YAWATA, Y. Atlas de doenças hematológicas: citologia e histologia. 1. ed. São Paulo: Manole Ltda, 1998.

44.ZAGO, M. A.; PASSETO, R. F.; PASQUINI, R. Hematologia: fundamentos e prática. 1. ed. Rio de Janeiro: Atheneu, 2001. 1081p.

45. ZAGO, M. A.; PASSETO, R. F.; PASQUINI, R. Hematologia: fundamentos e prática. Edição revisada. Reimpressão. Rio de Janeiro: Atheneu, 2005.

\section{MAILING ADDRESS}

\section{Luci Maria Sant'Ana Dusse}

Departamento de Análises Clínicas e Toxicológicas da Faculdade de Farmácia da Universidade Federal de Minas Gerais; Av. Professor Antônio Carlos, 6.627; Pampulha; CEP: 31270-901; Belo Horizonte-MG, Brazil; Tel.: (31) 3409-6880/6900; Fax: (31) 3409-6985; e-mail: lucim@farmacia.ufmg.br; lucidusse@ gmail.com. 